\title{
APPLICATION OF COMPUTER PROCESSED INTERPRETATIONS ON THE WELL LOG DATA OF BELAYIM LAND, TO EVALUATE SIDRI MEMBER HYDROCARBON RESERVOIRS, GULF OF SUEZ, EGYPT.
}

\author{
EL-KADI, $\mathrm{H}^{(1)}$, ESSA, $\mathrm{A}^{(2)}$ AND OMAR, $\mathrm{M}^{(2)}$ \\ (1) AL-AZHAR UNIVERSITY, (2) BELAYIM PETROLEUM COMPANY, CAIRO, EGYPT.
}

\begin{abstract}
The present study deals with a comprehensive interpretation of the available digital well-log data of Belayim Land area, using a computer program (Interactive Petrophysics) to evaluate Sidri Member. The corresponding well-log data have been processed through a sequence of graphical relations (manual interpretation) to evaluate quantitatively the different petrophysical characteristics and also computerized through the available computer software. The manual interpretation was started by subdividing the studied member (Sidri Member) into zones and the log readings were tabulated. These zones are correlated between wells, according to their remarkable changes in the log responses and their similarity. Tri-porosity (M-N) cross-plots for mineral identifications are used to detect, in general, the types of lithology. Lithologic identification is achieved through the cross-plots between $\rho_{b}, \varnothing_{n}$ and $\Delta_{t}$, to detect the matrix density $\left(\rho_{m a}\right)$ and matrix interval transit time $\left(\Delta t_{m a}\right)$ for each facies. These charts show that the sandstone and shale represent the main components in Sidri Member. The mono-porosity cross-plots are constructed to determine the water saturations $\left(S_{w}\right)$, formation water resistivity $\left(R_{w}\right)$ and sonic, neutron and density derived porosities $\left(\varnothing_{s}, \varnothing_{n}\right.$ and $\left.\varnothing_{d}\right)$. Dia-porosity cross-plots were established to determine the shale volume $\left(V_{s h}\right)$ and effective porosity $\left(\varnothing_{\text {eff }}\right)$. All petrophysical characteristics, inferred from the previous steps, were represented vertically in the form of petrophysical data logs $(P D L)$. The lateral variations of the petrophysical characteristics are represented in the form of iso-parametric maps (effective thickness, shale content, effective porosity and hydrocarbon saturation). It is worth-mentioning that, also the litho-saturation cross-plots illustrated from the computer processed interpretation are correlatable with the manual ones. The petrophysical characteristics of Sand3 (Sidri Member) reflect the ability of this unit to store and produce hydrocarbon. Effective porosity ranges between 12 and $24 \%$, shale content varies from 0 and $27 \%$ and hydrocarbon saturation ranges between 75 and $92 \%$. The petrophysical characteristics of Sand2 (Sidri Member) reflect the ability of this unit also to store and produce hydrocarbon. Effective porosity ranges between 3 and 20\%, shale content varies from 0 and $52 \%$ and hydrocarbon saturation ranges between 31 and 89\%. Sand 1 (Sidri Member) petrophysical characteristics reflect high ability to store and produce hydrocarbon more or less like Sand 3 unit. Effective porosity ranges between 14 and 24\%, shale content varies from 0 and $19 \%$ and hydrocarbon saturation ranges between 51 and 87\%. It is clear that, Sand1 and Sand 3 units show better reservoir characterization than that of Sand2 unit.
\end{abstract}

\section{INTRODUCTION}

Belayim Land field is located in the central part of the Gulf of Suez, along the western coast of the Sinai Peninsula. Together with Belayim Marine and Abu Rudeis -Sidri fields, it forms the Abu Rudeis oil district operated by Petrobel Oil Company. The Belayim Land Development area is operated by Petrobel Operating Company on behalf of the concession shareholders, EGPC $50 \%$ and IEOC $50 \%$. Belayim Land is a multilayer field with several separated sandstone reservoirs interbedded with shales and anhydrite intercalations, ranging from Early to Late Miocene in age and named (Zeit Fm, South Gharib Fm, Hammam Faraun Mbr, Feiran Mbr, Sidri Mbr, Kareem Fm, and Rudeis Fm). From a structural point of view, the field can be described as a N-S trending anticline (10 Km long and $4 \mathrm{Km}$ wide) cut by two main fault systems. The main faulting system is parallel to the coast (NW-SE) and is related to the rifting of the Gulf of Suez, while the secondary ENE-WSW trend subdivides the structure into several sectors. As a result, this complex structural setting is characterized by the presence of several independent structural blocks. On the western side of the structure, there is communication with its offshore analogue, Belayim Marine Field. The two fields resulted to be in a dynamic communication through a common reservoir. The field was discovered at the beginning of 1954 and it was put on production on September 1955. Water injection started in 1985, when the field was already partially depleted, with volumes suitable to balance the hydrocarbon withdrawal. 


\section{LOCATION OF THE STUDY AREA:}

Belayim Land Field is one of the large oil fields in the Gulf of Suez. It is located in the central part of the eastern coast of the Gulf of Suez, south of Abu Rudeis town (Fig. 1).

\section{AIM OF THE PRESENT STUDY:}

Based on the vertical and lateral variations of petrophysical characteristics, the main target of the present study is the evaluation of hydrocarbon reservoir Sidri Member at Belayim Land oil field. This target is achieved, manually through cross-plots and analytically through the application of sophisticated computer software, to determine the petrophysical characteristics in the area under investigation. These characteristics include; shale content, effective porosity and water and hydrocarbon saturations by using the Density, Resistivity, Neutron porosity, Sonic and Gamma-ray logs. Computer programs have been applied to the studied rock unit (Sidri Member), that penetrated by nine wells distributed in the study area. The performance of the formation evaluation operation in the reservoir analysis and hydrocarbon prospection depends essentially on the refinement of the previously developed log analysis methods, by using computer facilities.

\section{PERVIOUS RELATED WORKS:}

The geology of the Gulf of Suez was studied by many workers. In the following paragraphs, the reviews of the structure, stratigraphy and petroleum potentiality of the Gulf of Suez are given.

\section{TECTONICSETTINGOFTHEGULFOFSUEZ:}

The Gulf of Suez originated as a depositional realm, that dated back to Early Paleozoic time. Contrary to the Red Sea and the Gulf of Aqaba, which were formed by up warping of the Nubian-Arabian shield with its subsequent rifting, transform faulting and final break apart, the Gulf of Suez came into being as a result of tensional movement and subsidence along the NW-SE trending normal faults, probably prior to the Devonian time. They produced a relatively narrow embayment in the foundered part of the Precambrian basement between the present Sinai Peninsula and the Eastern Desert, as far as Hurghada, that situated on the northern end of the Red Sea. To the north, it opened into the ancient Tethys. In Oligocene-Miocene time, during the initial events of the East African rifting, the Gulf of Suez, as an area of crustal weakness followed suite and adapted itself to its present shape. The NNW-SSE Erythrean trend, the NS East African Rift trend, the NNE-SSW Aqaba trend and the E-W Tethyan trend are responsible for the development of the Gulf of Suez, as seen in Fig. 2 (GEXCO and JEBCO, 1975). The Erythrean trend, controls to a large extent, the normal faults flanking and running parallel to the present Gulf of Suez. The age of this trend is still debated. Schurmann (1971) attributed it to a Precambrian age and believed the graben to be of ancient origin. This is supported by the fact that, the narrow north-south embayment is infilled with Paleozoic deposits from the north, as far as Hurghada. Youssef (1968) interpreted the graben to be the result of a stress pattern over a prolonged period, but found its present shape from the Upper Mesozoic onwards, caused in part by the tensional movements, and in other part as a result of rotational movements between the Nubian and Sinai plates. Most likely the Gulf of Suez area was a zone of crustal weakness since the Precambrian times. The East African trend gives the coast line a sort of zigzag appearance more pronounced in the Red Sea than in the gulf area. The Aqaba trend is thought to have affected the Gulf of Suez with slight rotation of fault blocks. The Tethys trend is limited to the extreme north east and is manifested by gently folding of pre-Pliocene formations. This trend is related to the Alpine Orogeny and is also referred to as the Syrian trend. The combined effect of these tectonic events led to intense structuring and break-up into an enormous number of fault blocks composed of formations ranging in age from Precambrian to Eocene. The fault blocks raised and foundered in a key-board manner and changed the depositional environment within relatively small areas. Deep water deposition occurred in the lows between the blocks, whereas coarse clastic formations were caught in the lows of the tilted block surfaces, and reefal build-ups were formed along the high edges of the fault blocks. Other lifted blocks, emerged from the sea, were exposed to erosion. 


\section{REGIONAL GEOLOGICAL FRAME WORK:}

The tectonic setting of the Gulf was conditioned by tensional and subsidence movements along the NW-SE trending normal faults, probably of Pre-Devonian Age. They produced a relatively narrow embayment in the foundered part of the Precambrian basement. In OligoceneMiocene times, during the initial events of the East African rifting, the Gulf of Suez, as an area of crustal weakness, followed suite and adapted itself to its present shape (Fig. 3). In this structural framework the Belayim Area is the results of the interference of two main extensional fault systems related to the opening of the gulf; the rifting phases derived from the movement of the African plate to the West and the Arabic microplate to the East generated horst and graben geometries. The current seismic interpretation of Belayim Land highlighted an anticline structure elonged in the NNW/SSE trend, approximately parallel to a regional fault dipping westward (Main Fault) and that borders the field in all its section, from the Lower Miocene until post Miocene. Moreover, the structure is complicated by the presence of two tectonic systems; the prevalent one is oriented NNW/SSE with a secondary one NNE/SSW. The final result is a complex structural setting, characterized by the presence of different blocks, often difficult to work with in terms of identification of the degree of hydraulic communication among them.

\section{WELL-LOG ANALYSIS}

Well-log analysis represents the most important stage in the evaluation of petrophysical characteristics, which involve shale content, effective porosity, water and hydrocarbon saturations. In this study, two processes were applied to evaluate the petrophysical characteristics of Sidri Member. The first one is the manual evaluation, which depends on using of charts and crossplots, while the second process is the application of computer softwares (computer processed interpretation). Manual interpretation techniques continue to be used with first generation equipments. With modern equipments, fast or simplified interpretations can be made at the well-site. Evaluation methods have evolved rapidly in recent years, as the result of more numerous and efficient tools, as well as the calculating capacity of computer, which is using now a day during well operations. Highly efficient computer software provides complete and accurate evaluation. Interactive Petrophysics software (IP) is used in this study.

\section{MANUAL FORMATION EVALUATION:}

Manual evaluation for the determination of petrophysical parameters $\left(\mathrm{V}_{\text {sh }}, \varnothing_{\text {eff }}, \mathrm{S}_{\mathrm{w}}\right.$ and $\left.\mathrm{S}_{\mathrm{hr}}\right)$ was obtained graphically to evaluate Sidri Member by exploration of its reservoir capability for petroleum accumulation. In this study, the manual evaluation process passes through qualitative and quantitative interpretation techniques. Quantitative techniques are based on a series of empirical relationships and models or cross plots derived from simultaneous equations (Burke et al. 1969).

\section{PRINTING OF WELL LOGS:}

The printing of well logs involves by converting the digital well-log data to hard copies.

\section{QUALITATIVE CORRELATION:}

It is the process of comparing one log with another of the same type or different types and enables the interpreter to obtain more information (larger scale) than can be derived from only one $\log$ (smaller scale).

\section{QUANTITATIVE ANALYSIS:}

Quantitative log analysis is based on a series of empirical relationships or models.

\section{M-N (TRI- POROSITY) CROSS-PLOT:}

This technique depends on the fluid and $\log$ parameters, which are incorporated together essentially in the three porosity logs; Sonic, Density and Neutron. In complex lithology, the M-N Cross Plots or Tri-porosity Cross Plots are used to identify mineral mixtures. From the values of these porosity logs, two functions ( $\mathrm{M}$ and $\mathrm{N}$ ) are calculated, which are independent of the primary porosity; therefore a cross-plot of these two quantities gives lithologic classification generally (Pirson, 1977). By using the M-N Plot for mineral identification, the lithologic content for each zone can be defined, with respect to the standard M-N values of common minerals and rocks (Schlumberger, 1972) (Fig. 4). 


\section{LITHOLOGIC IDENTIFICATION:}

Logs can be used as indicators of lithology. The most useful logs for this purpose are Density, Neutron and Sonic. An important technique gives an accurate result for lithologic identification is the use of cross-plots (Schlumberger charts) between $\varnothing_{\mathrm{SNP}} \mathrm{Vs} \rho_{\mathrm{b}}$ and $\varnothing_{\mathrm{SNP}} \mathrm{Vs} \Delta \mathrm{t} \log$ readings to obtain the lithologic characteristics. Different charts can be applied to obtain the type of each lithologic component of Sidri Member and to determine the apparent $\rho_{\mathrm{ma}}$ and apparent $\Delta \mathrm{t}_{\mathrm{ma}}$ for each level. (Figs. $5 \& 6$ ).

\section{MONO-POROSITY CROSS-PLOTS:}

Mono-porosity cross plot (Resistivity / Porosity) is a convenient way to demonstrate how various log combinations are responded to saturation and porosity. Furthermore, the logs respond to the pore' fluids, which affect greatly the log readings. Also, Density and Neutron logs are affected differently in the presence of gas or light hydrocarbon. Mono-Porosity cross plots were carried out to determine the formation water resistivity $\left(\mathrm{R}_{\mathrm{w}}\right)$, water saturations $\left(\mathrm{S}_{\mathrm{w}}\right)$ and the derived porosities $\left(\varnothing_{\mathrm{s}}, \varnothing_{\mathrm{d}}\right.$ and $\left.\varnothing_{\mathrm{n}}\right)$ (Figs. 7-15). ResistivityPorosity cross plots require that, formation water resistivity is constant over the plotted interval, that lithology is constant, and that the measured porosity $\log$ parameters $\left(\rho_{\mathrm{b}}, \Delta \mathrm{t}_{\log }\right.$ and $\left.\varnothing_{\mathrm{n}}\right)$ can be linearly related to resistivity. Three values of water saturation $\left(\mathrm{S}_{\mathrm{ws}}, \mathrm{S}_{\mathrm{wd}}\right.$ and $\left.\mathrm{S}_{\mathrm{wn}}\right)$ and three derived porosities $\left(\varnothing_{\mathrm{s}}, \varnothing_{\mathrm{d}}\right.$ and $\left.\varnothing_{\mathrm{n}}\right)$ corresponding to each horizon are detected directly from the cross plots and tabulated. The mean values of $S_{w}$ and $\varnothing$ have been obtained. The matrix parameters $\left(\Delta t_{\text {ma }}, \rho_{\text {ma }}\right)$ of these plots are selected as $55 \mu \mathrm{sec} / \mathrm{ft}$ and 2.66 $\mathrm{gm} / \mathrm{cc}$, respectively.

\section{DIA-POROSITY CROSS-PLOTS:}

For the determination of effective porosity $\left(\varnothing_{\text {eff }}\right)$ and shale volume $\left({ }_{\mathrm{Vsh}}\right)$, combinations of porosity logs can be used. Three plots are used $\left(\rho_{\mathrm{b}} \mathrm{Vs} \emptyset_{\mathrm{n}}, \Delta \mathrm{t}_{\log } \mathrm{Vs} \rho \mathrm{b}\right.$ and $\Delta \mathrm{t}_{\log } \mathrm{Vs}_{\mathrm{n}}$ ) for each lithologic unit within the formation. The effective porosity and shale content for each zone are estimated by calculating the mean value of the obtained $\varnothing_{\text {eff }}$ and $\mathrm{V}_{\text {sh }}$. (Figs. 16-18) are representing the Dia-porosity cross-plots for the studied layers.

\section{GRL - RECALIBRATION CURVE:}

GRL was constructed to make sure that, it can be recalibrated, as shown in Fig. (19). The API calibration, based on the use of a permanent calibration facility, to establish standard units for nuclear logs.

\section{DISPERSED-LAMINATEDSHALEMODEL:}

Shaly material can be distributed in the formation through three ways; Laminated, structural and dispersed in the shaly sand (Darwin, 1987). Laminated shale is discrete layers of shale in otherwise clean sandstone. In this case, the unit volume of formation is considered to share both matrix and porosity volume, with this type of shale. Structural shale is considered to be composed of grains consisting of rock matrix and clay particles. None of the pore volume is occupied by the shale. Dispersed shale is the shale, in which the clay is present throughout the system, dispersed in the pore space. Dispersed shale or clay minerals occurring at small volume concentrations are of great interest for hydrocarbon reservoir evaluation.

Fig. (20) illustrates the relationship for the difference between the sonic derived and density derived porosities $\left(\varnothing_{\mathrm{s}}-\varnothing_{\mathrm{d}}\right)$ and shale content $\left(\mathrm{V}_{\mathrm{sh}}\right)$. This relationship illustrates a general view about the shale type. The dispersed shale relationship is defined as $\left(\varnothing_{\mathrm{s}}-\varnothing_{\mathrm{d}}\right)=\mathrm{V}_{\mathrm{sh}}$ while the laminated one is defined as $\left(\varnothing_{\mathrm{s}}-\varnothing_{\mathrm{d}}\right)=0.13$ $\mathrm{V}_{\mathrm{sh}}$. As shown in the figure, most of the points represent shale in the area under investigation are located in the part close to laminated shale type. This means that, there is an indication of the presence of more or less laminated shale and it can be confirmed by the construction of shale model.

\section{SHALE TYPES:}

Since the Archie water saturation equation relates rock resistivity to water saturation and assumes that, the formation water is the only electrically conductive material in the formation. In shaly formations, it is required either that, the Archie equation be modified to be suitable for the existence of another conductive material or that a new model can be developed to relate rock 
resistivity to water saturation in shaly formation (Schlumberger, 1987). Fig. (21) represents the shale model, which exhibit the cross-plot of $\varnothing_{n}$ Vs $\varnothing_{\mathrm{d}}$ to determine the shale types present in the studied formations in the area under investigation. From this figure, it is clear that, the shale type in the studied rock unit is a mixture between the laminated and dispersed shales.

\section{COMPUTERPROCESSEDINTERPRETATION:}

One of the features of modern log interpretation is the systematic usage of computer softwares. This makes possible to rapid integration of several logging measurements, acquired separately, with all other available bore hole and geological information. As a result, the detection and evaluation of potential hydrocarbon-bearing zones can nowadays be generally achieved at the well-site, right after the logging operation (quick-look).

In this study, Interactive Petrophysics software (IP) is developed by Schlumberger, which has more or less inspired all other similar softwares, is used to evaluate the petrophysical characteristics of the studied formations in the form of litho-saturation plots. This Interactive Petrophysics computer program was designed for the quantitative formation evaluation of open and cased-hole logs (Fig. 22).

\section{ILLUSTRATION OF RESULTS}

In this study, the hydrocarbon potentialities of Sidri Member have been evaluated by studying the petrophysical characteristics for the different zones. The study of hydrocarbon saturation has been carried out through two main stages. The first stage is the lateral variation presentation, while the second stage is the vertical variation presentation.

\section{LATIERAIIARATIONOIFETROPHSCAICHARACIFRSIICS}

The lateral variation of petrophysical characteristics in the area under investigation could be studied through a number of gradient maps (isoparametric maps); that include, shale content $\left(\mathrm{V}_{\text {sh }} \%\right)$, effective thickness $\left(\mathrm{H}_{\text {eff }} \%\right)$, effective porosity $\left(\varnothing_{\text {eff }} \%\right)$ and hydrocarbon saturation $\left(\mathrm{S}_{\mathrm{hr}}\right.$ $\%)$ to complete the vision of hydrocarbon potentialities in the studied area. The study of these parameters on maps is very important for judging about their lateral variations and the factors controlling them, which may be either structural, stratigraphic or both.

\section{EFFECTIVE THICKNESS VARIATION:}

The effective thickness variation maps are constructed to illustrate the lateral variation of thinning and thickening of the effective thickness of the studied rock units.

\section{SHALE CONTENT VARIATION:}

Shale content is a quantitative function of $\log$ analysis. It is considered as an important indicator of reservoir quality, in which lower shale content usually reveals a better reservoir quality.

\section{EFFECTIVEPOROSITYDISTRIBUTIONVARIATION:}

Effective porosity is the most significant petrophysical character in the evaluation of hydrocarbon potentiality. The structural element may affect porosity development, which has a great influence on porosity (EI Kadi et al., 2002).

\section{HYDROCARBONSATURATIONVARIATION:}

Determination of hydrocarbon saturation is the main target in the current study.

Figs. (23-25) illustrate combined petrophysical characteristics for Sand 3, Sand 2 and Sand 1 layers within Sidri Member.

\section{VERITCAIIARIATIONSOPEIROPHISICAICHARACIER- ISTICS:}

The vertical distribution of petrophysical characteristics have been performed through the litho-saturation cross-plots both manually and computerized. Litho-saturation cross-plot is a representation way, zone-wise, for the contents of fluids including water and hydrocarbon saturations. The vertical distribution of petrophysical characteristics is represented both manually in the form of petrophysical data logs (PDL) and computerized in the form of litho-saturation cross plots (CPI) (Figs. 26-34). 

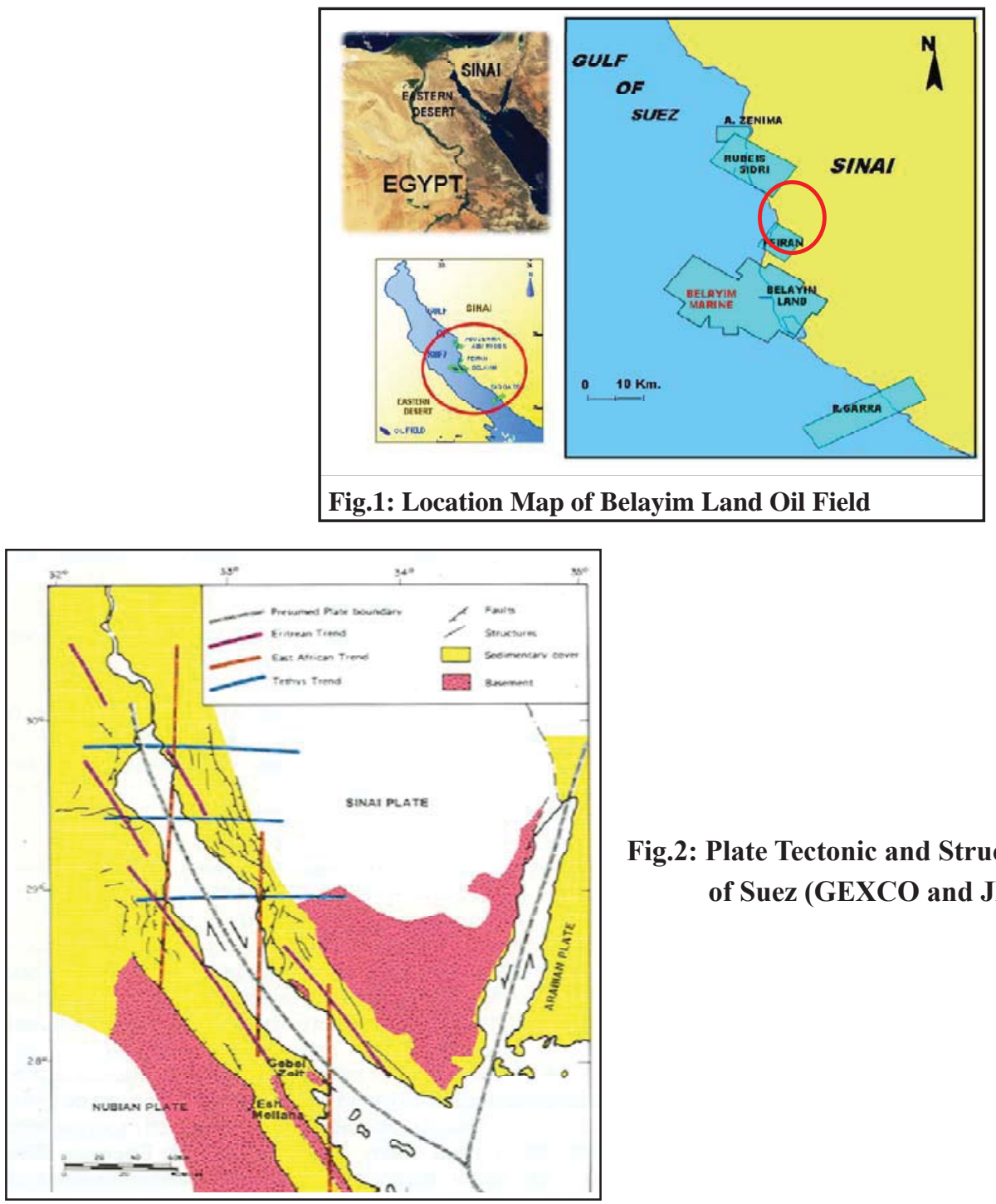

Fig.2: Plate Tectonic and Structural Trends in the Gulf of Suez (GEXCO and JEBCO, 1975).
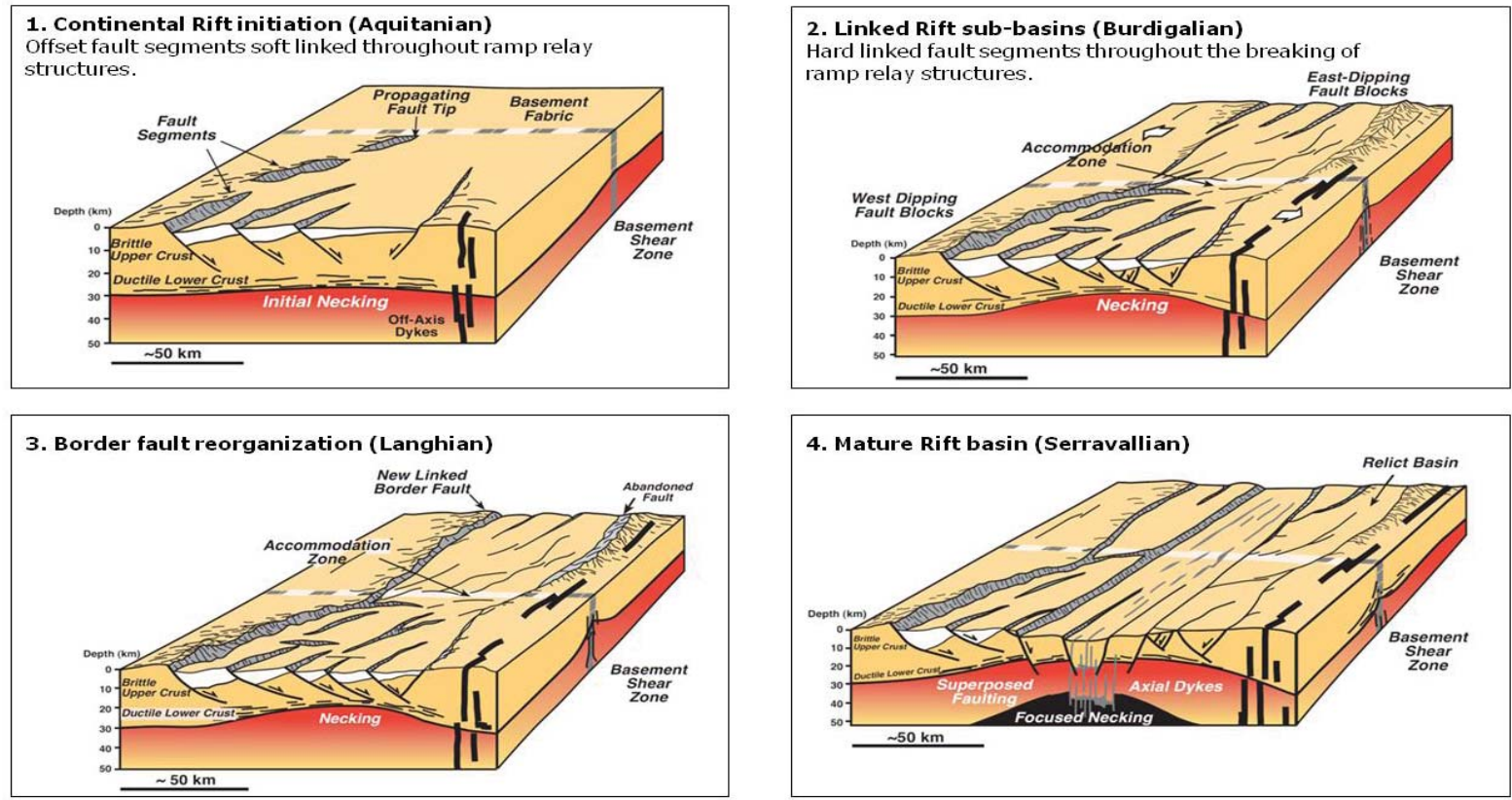

Fig.3: Gulf of Suez Basin Evolution. (Bosworth 1994; McClay and Khalil 1998) 

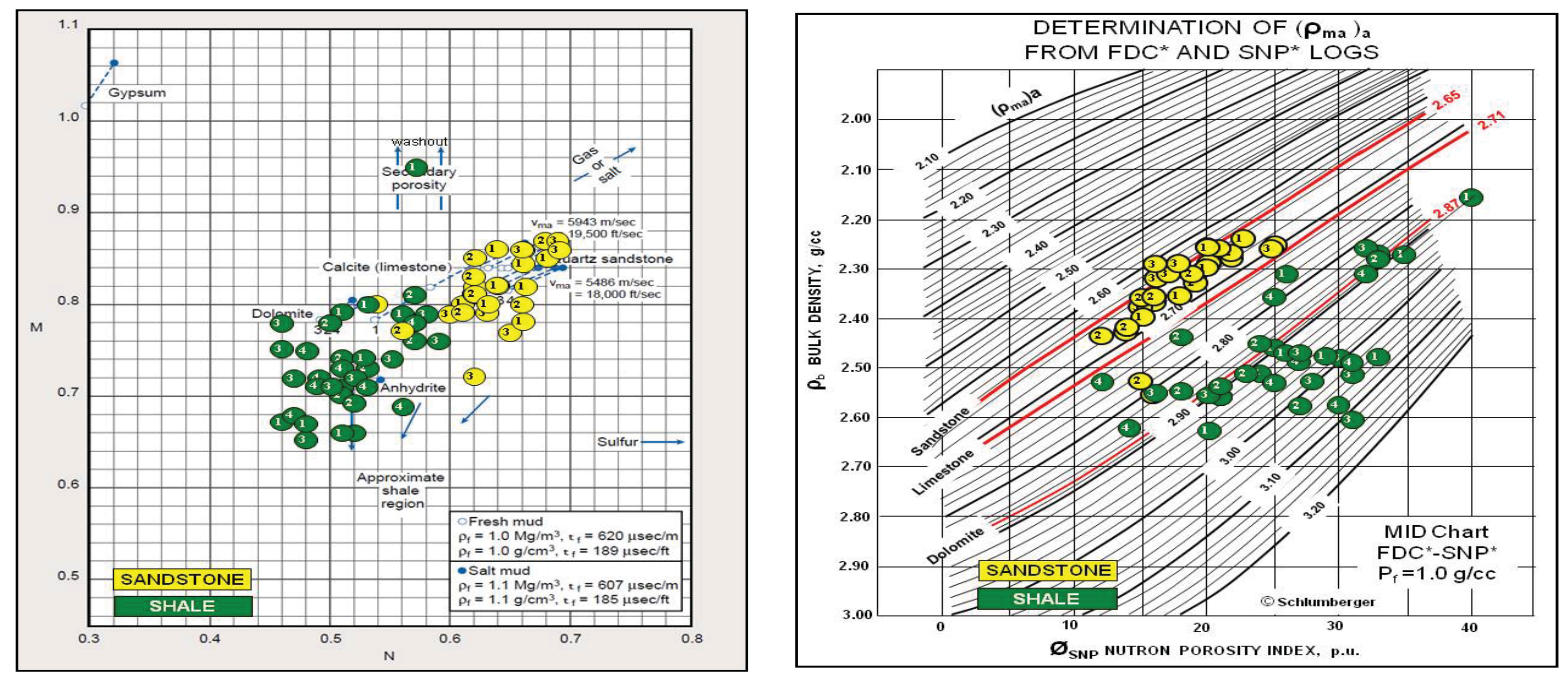

Fig.4: M-N Cross-Plot of Sand3, Sand2 and Sand1 Fig.5: Lithologic Identification (ØSNP Vs $\rho b)$ Cross for the Studied Wells.

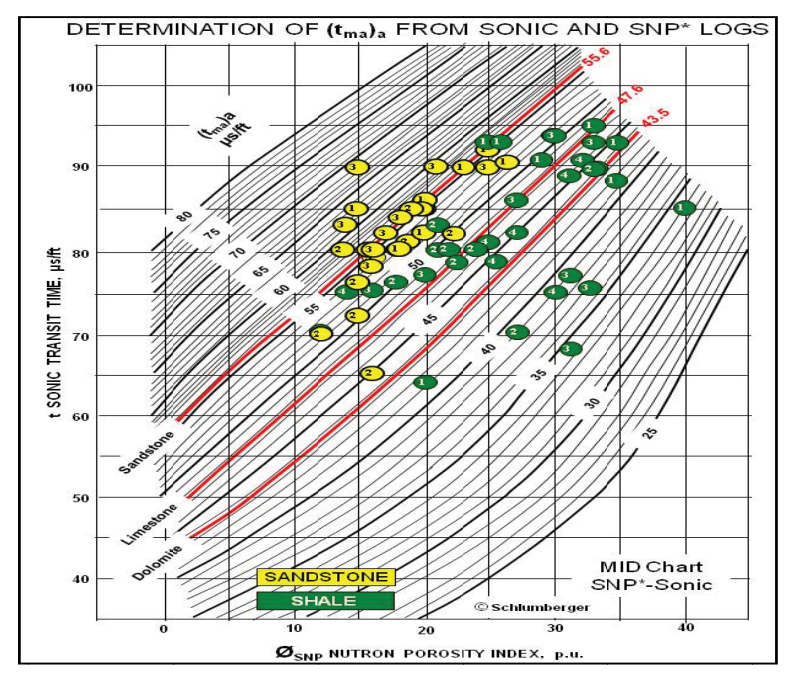
Plot of Sidri Member.

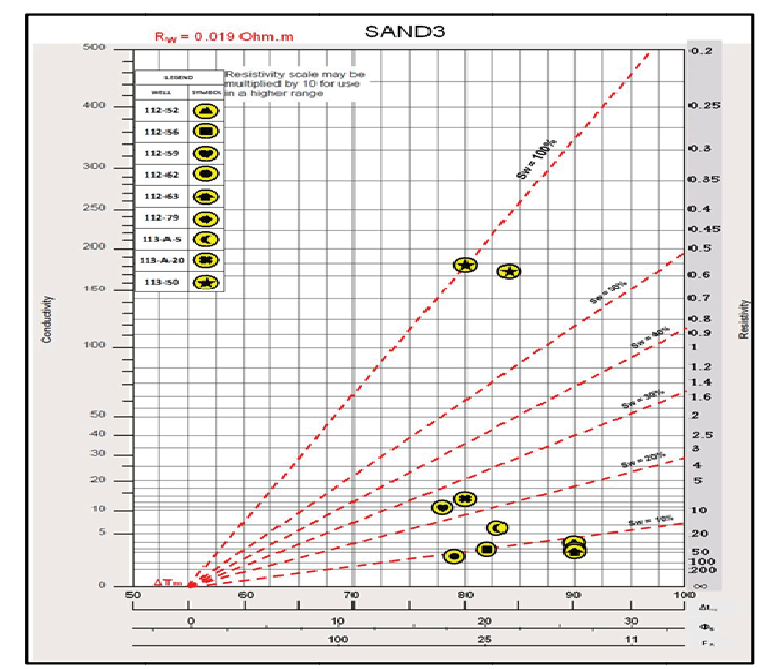

Fig.6: Lithologic Identification (ØSNP Vs $\Delta t)$ Cross Plot of Sidri Member

Fig.7: Mono-Porosity Cross-Plots of Sand 3 Using Sonic Log Readings
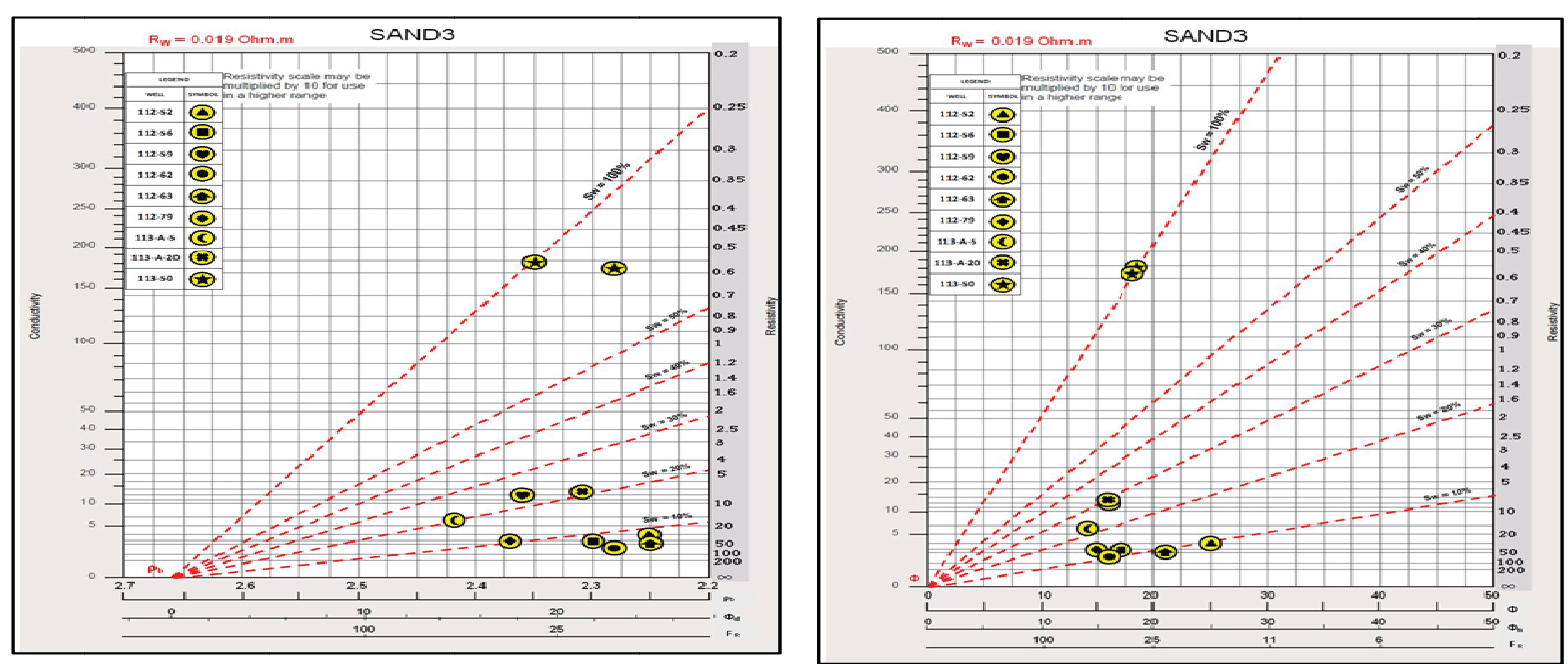

Fig.8: Mono-Porosity Cross-Plots of Sand 3 Using Fig.9: Mono-Porosity Cross-Plots of Sand 3 Using Density Log Readings

Neutron Log Readings 

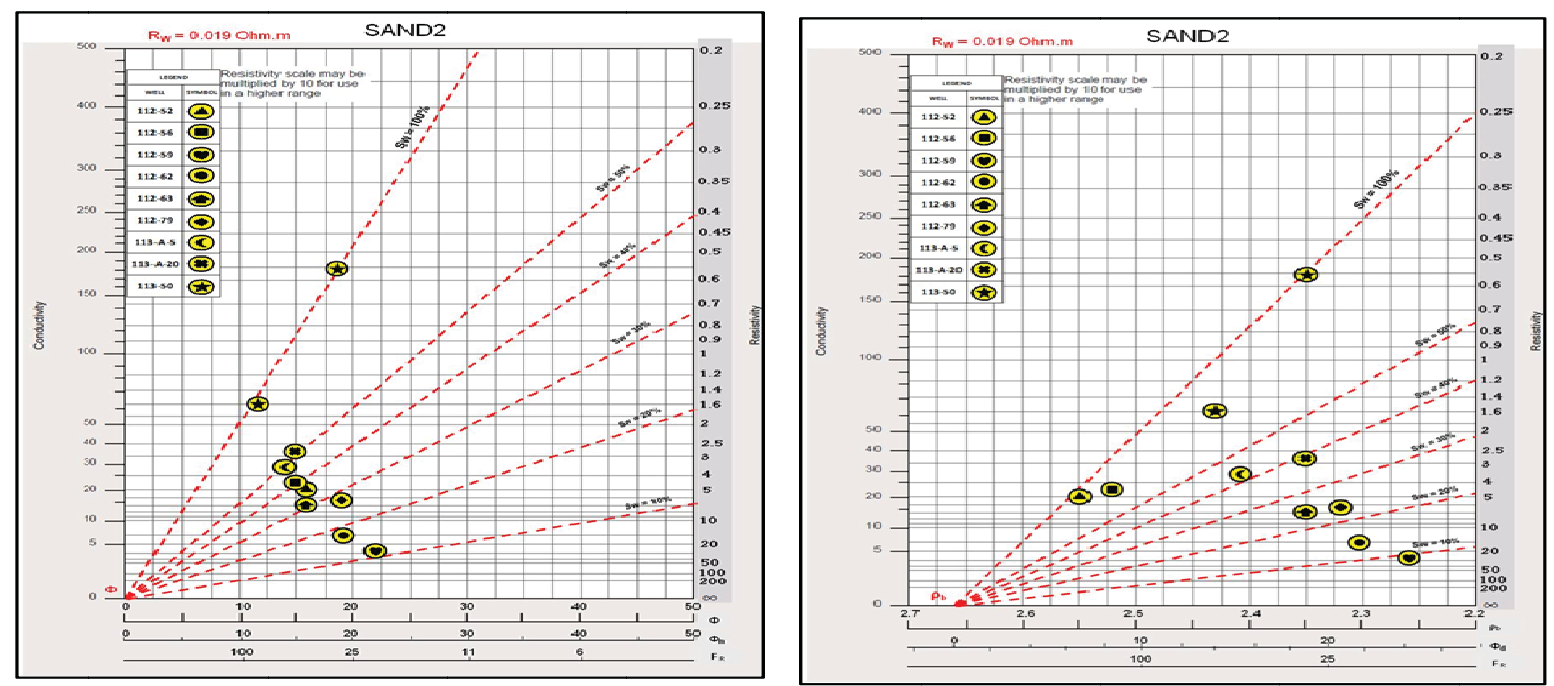

Fig.10: Mono-Porosity Cross-Plots of Sand 2 Using Fig.11: Mono-Porosity Cross-Plots of Sand 2 Using Sonic Log Readings

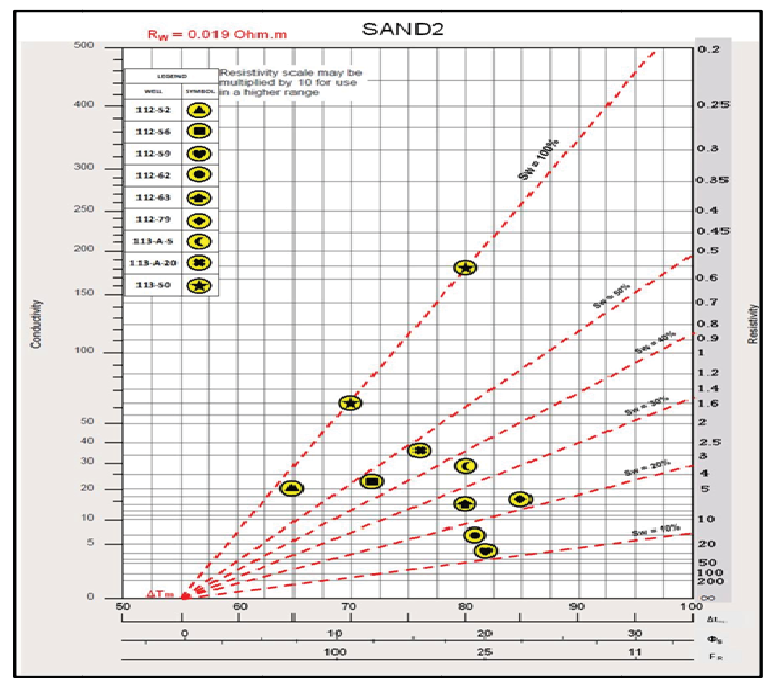
Density Log Readings

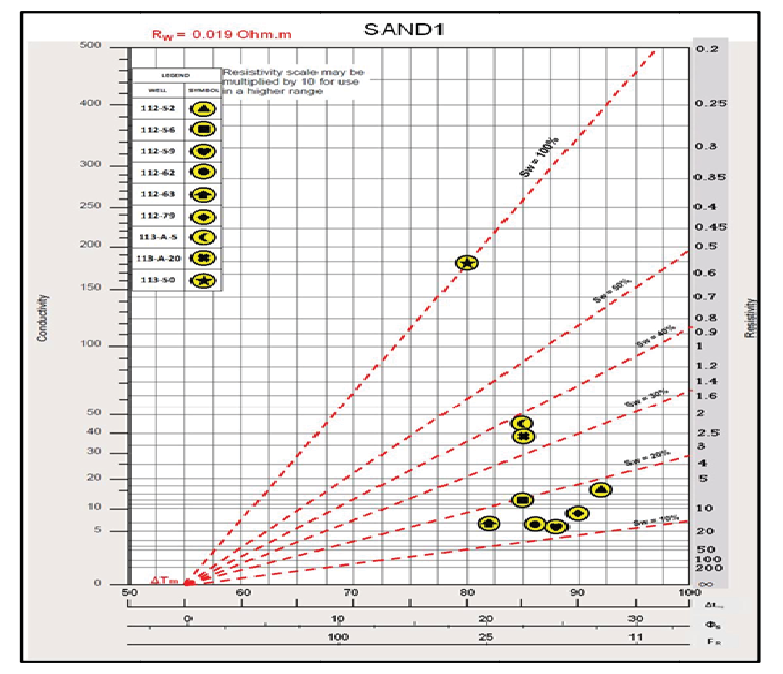

Fig.12: Mono-Porosity Cross-Plots of Sand 2 Using Neutron Log Readings

Fig.13: Mono-Porosity Cross-Plots of Sand 1 Using Sonic Log Readings
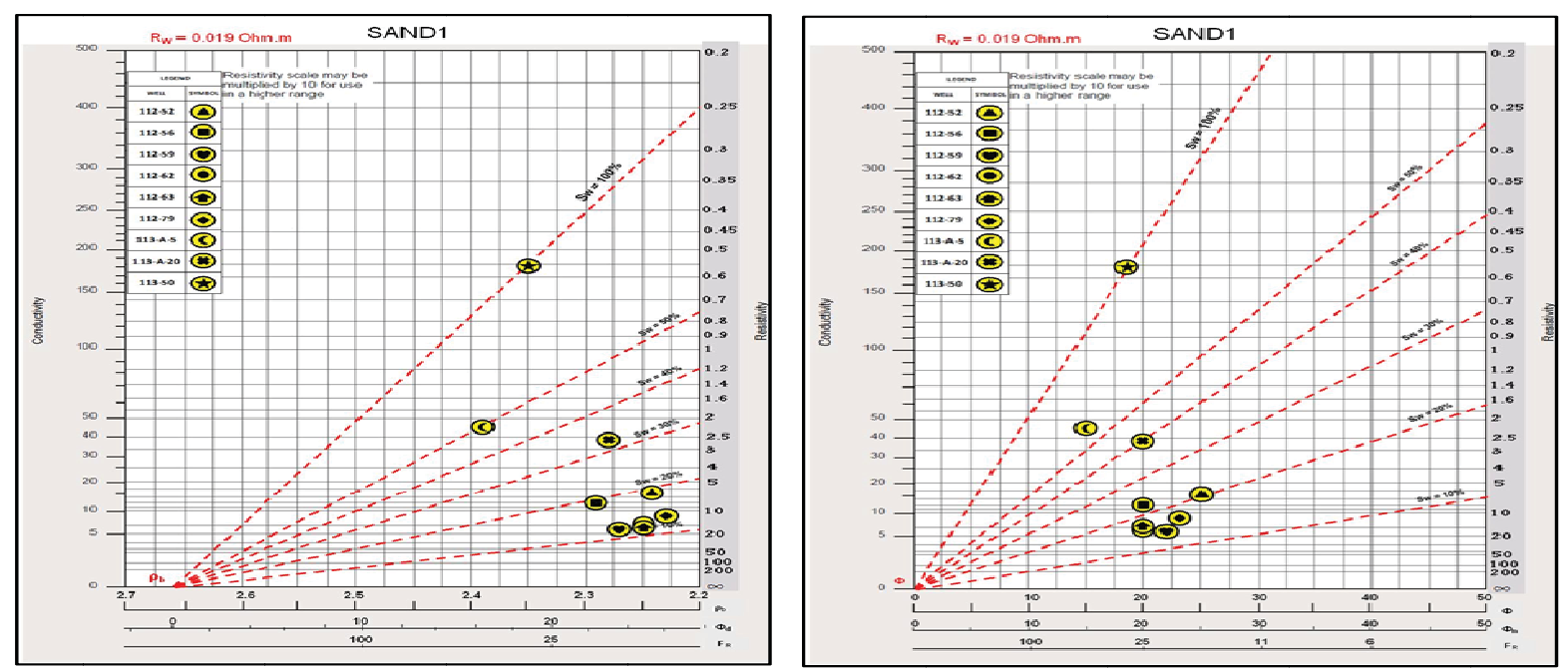

Fig.14: Mono-Porosity Cross-Plots of Sand 1 Using Fig.15: Mono-Porosity Cross-Plots of Sand 1 Using Density Log Readings Neutron Log Readings 


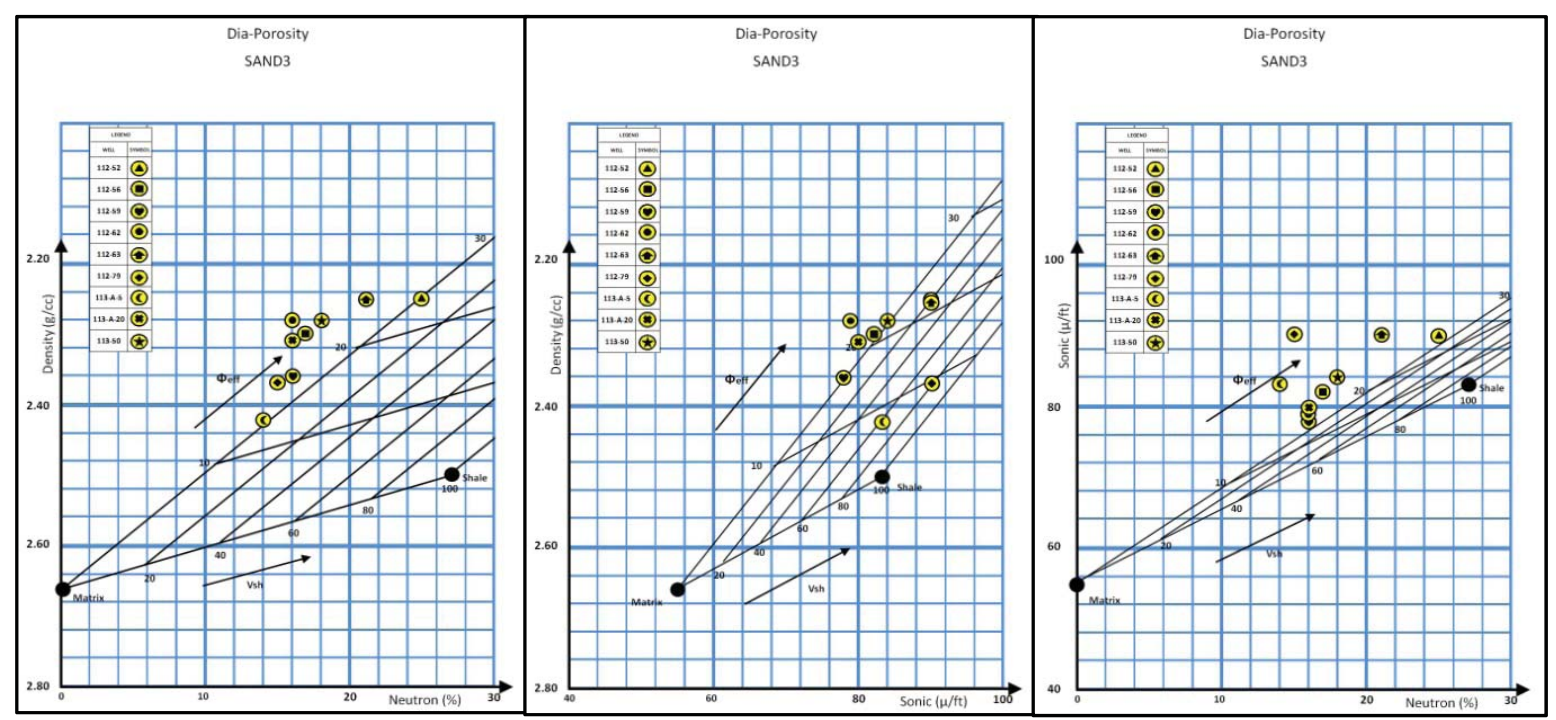

Fig.16: Dia-Porosity Cross-Plots of Sand 3 for the Studied Wells.

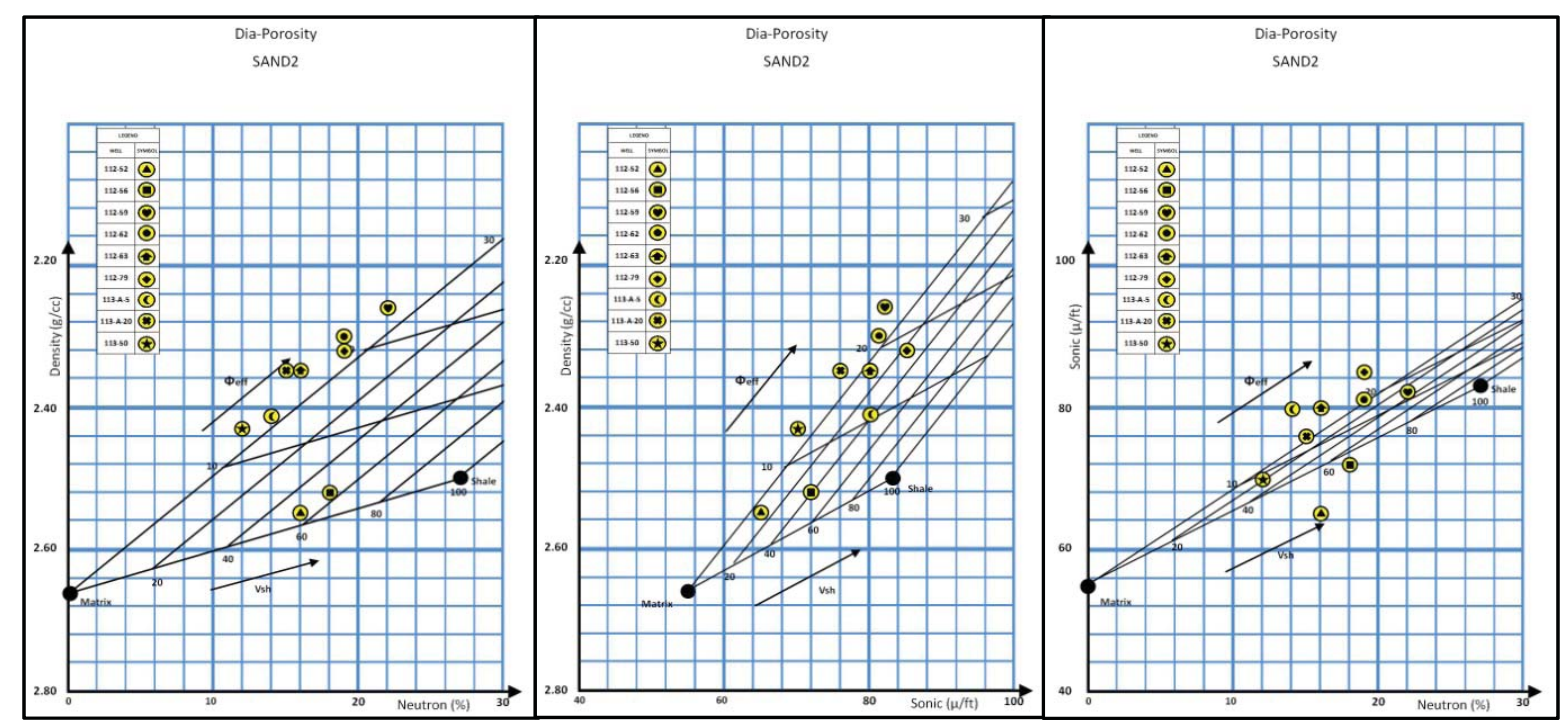

Fig.17: Dia-Porosity Cross-Plots of Sand 2 for the Studied Wells.

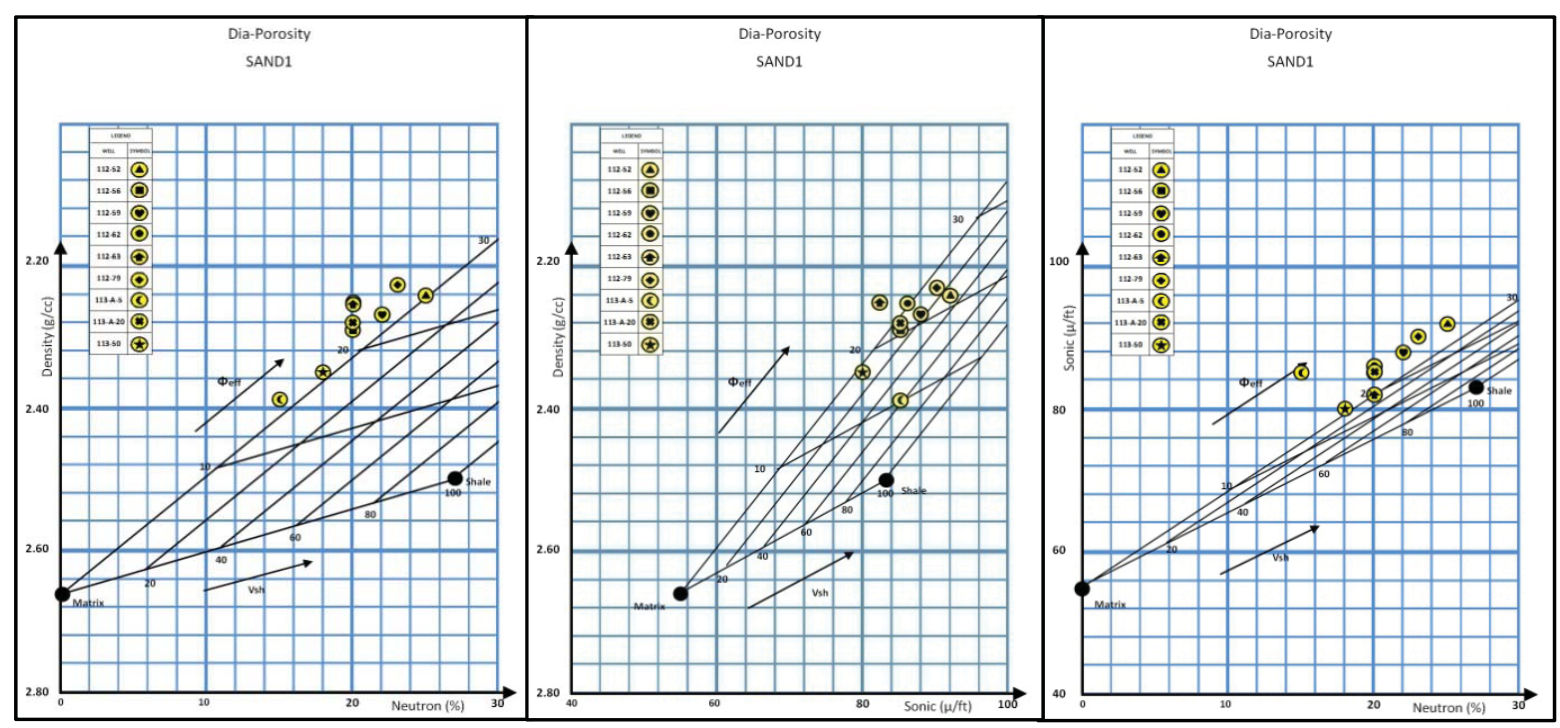

Fig.18: Dia-Porosity Cross-Plots of Sand 1 for the Studied Wells. 


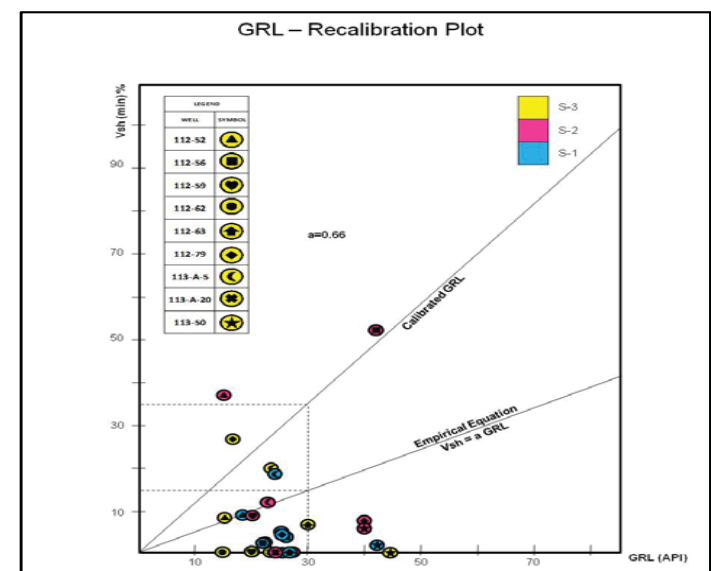

Fig.19: GRL - Recalibration Plot

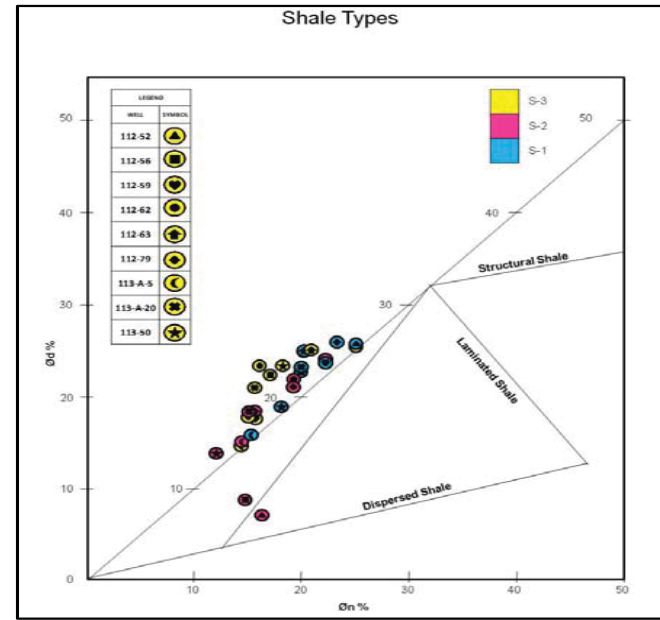

Fig.21: Shale Types of Sidri Member

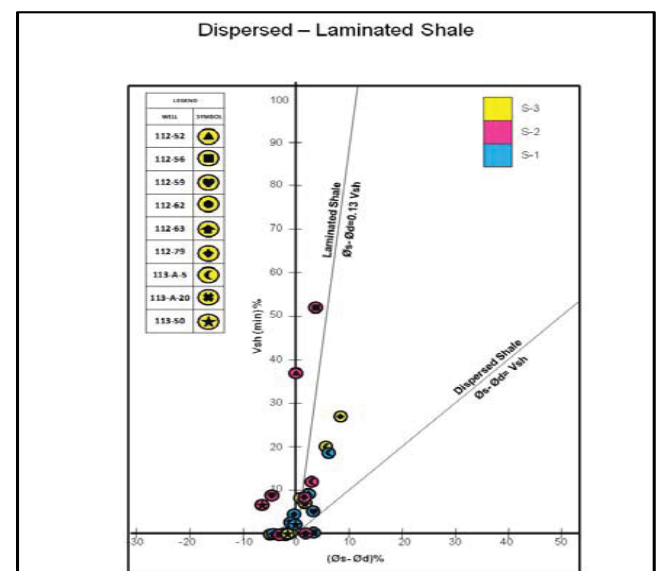

Fig.20: Dispersed - Laminated Shale Model of Sidri Member

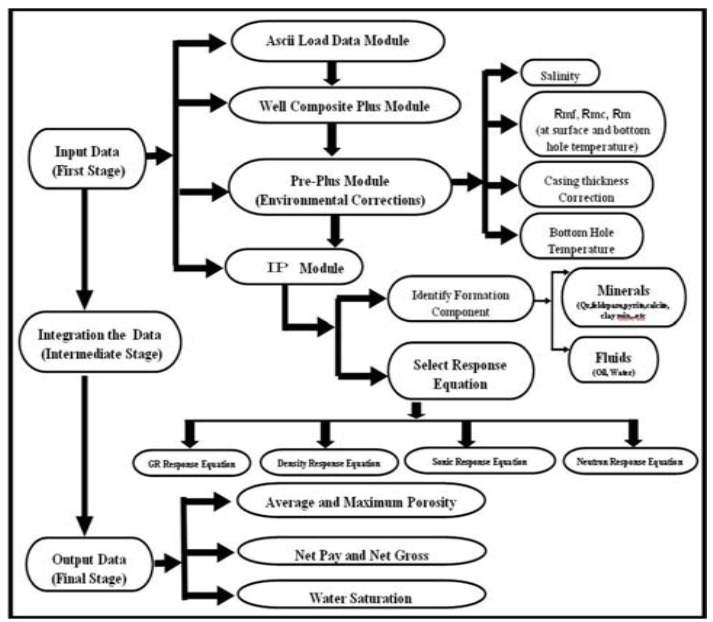

Fig.22: Simplified Flow Chart of IP Software

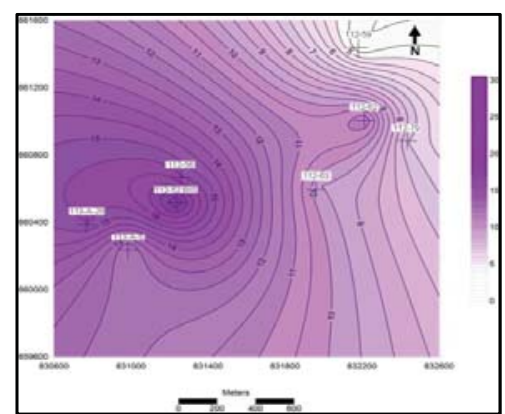

Effective Thickness (m)

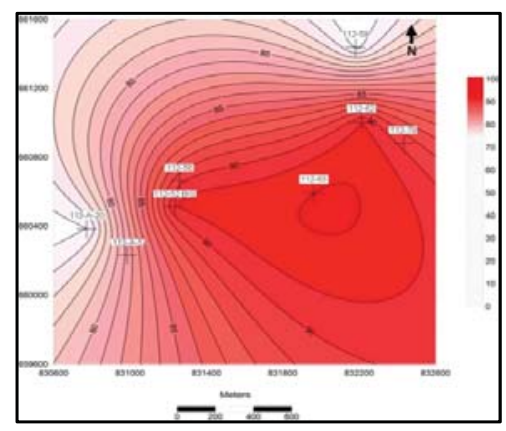

Hydrocarbon Saturation (\%)

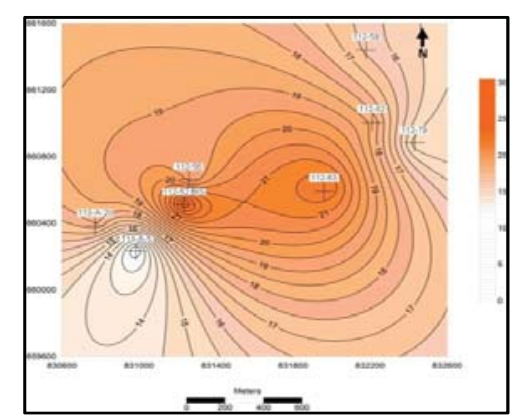

Effective Porosity (\%)

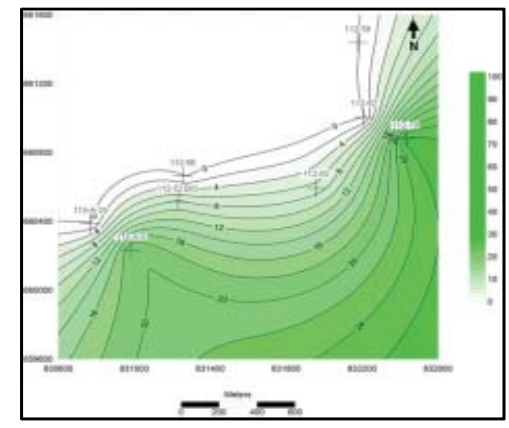

Shale Content (\%)
Fig.23: Combined Petrophysical Parameters for Sand 3 in the Studied Area. 


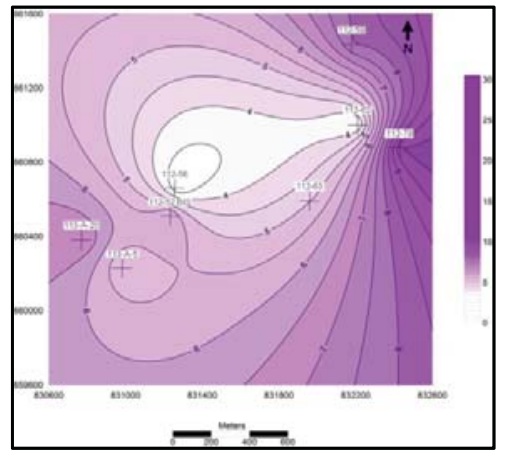

Effective Thickness (m)

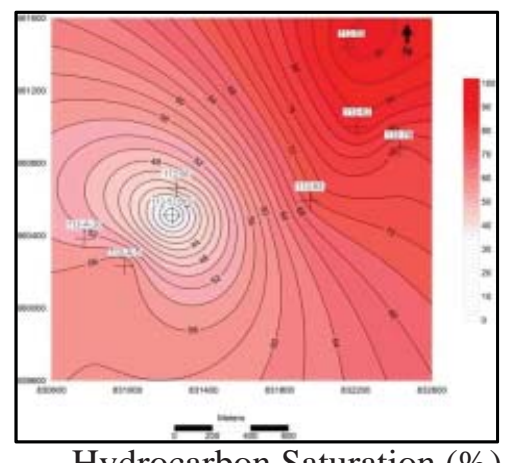

Hydrocarbon Saturation (\%)

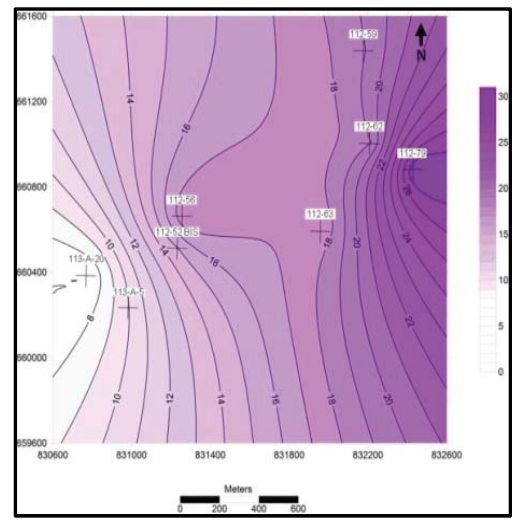

Effective Thickness (m)

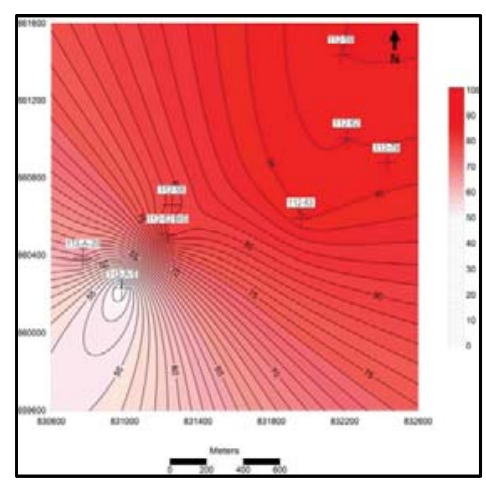

Hydrocarbon Saturation (\%)

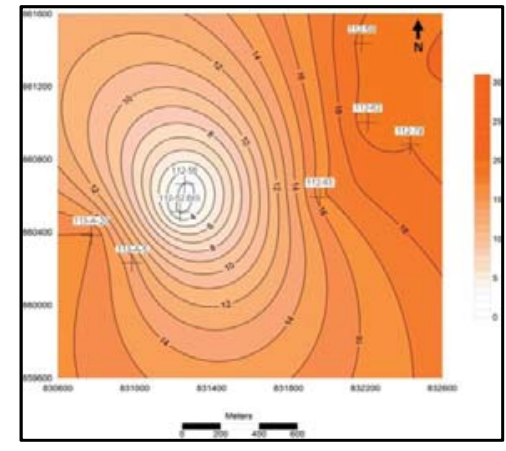

Effective Porosity (\%)

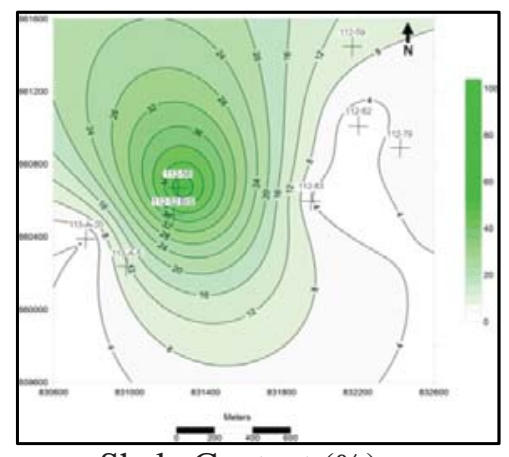

Shale Content (\%)
Fig.24: Combined Petrophysical Parameters for Sand 2 in the Studied Area.

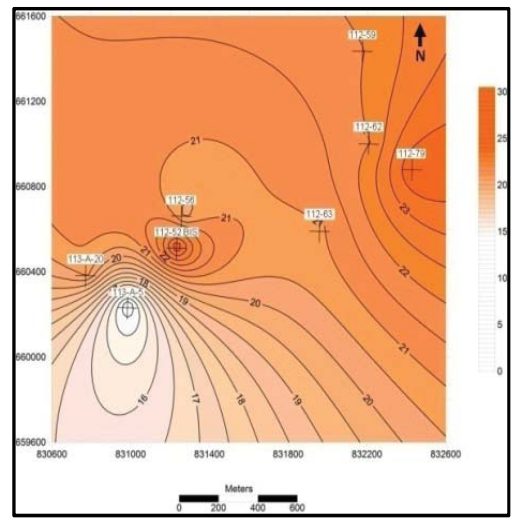

Effective Porosity (\%)

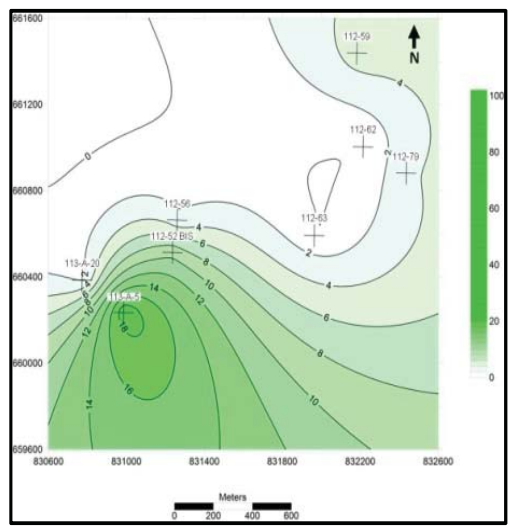

Shale Content (\%)
Fig.25: Combined Petrophysical Parameters for Sand 1 in the Studied Area. 


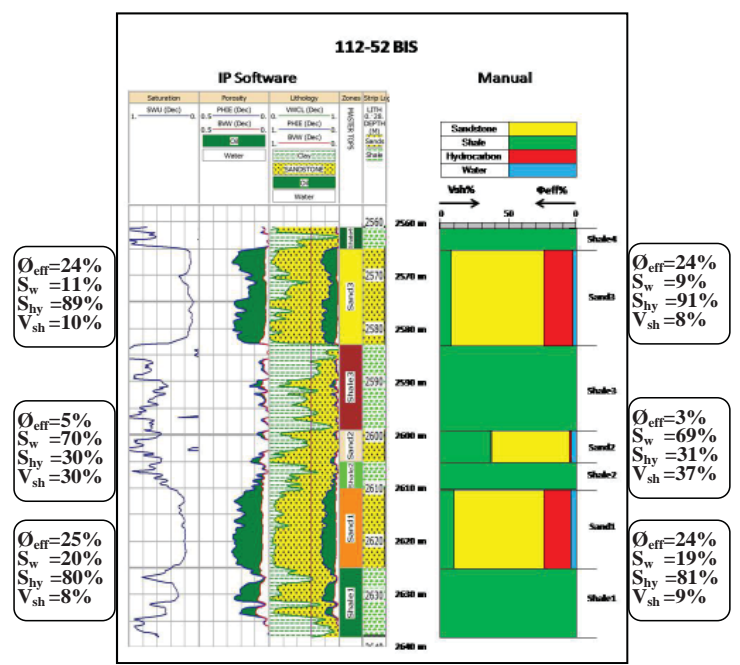

Fig.26: Comparison between Manual and Comput- Fig.27: Comparison between Manual and Computererized PDL for 112-52 (BIS) Well.

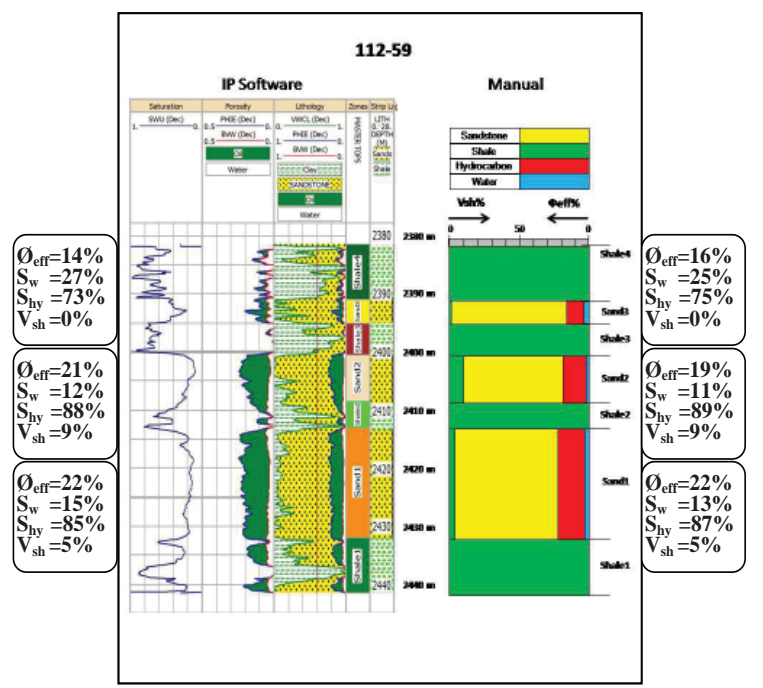

Fig.28: Comparison between Manual and Comput- Fig.29: Comparison between Manual and Computererized PDL for 112-59 Well.
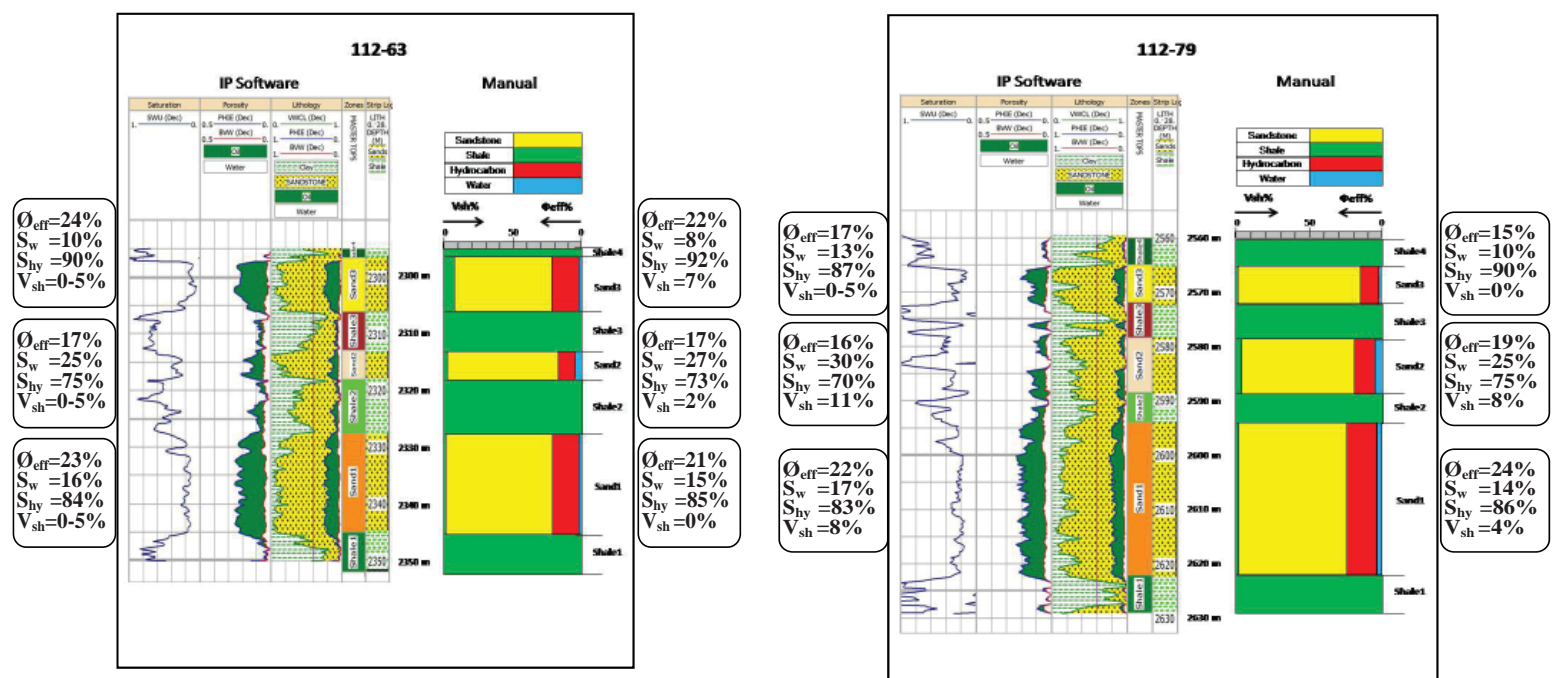

Fig.30: Comparison between Manual and Comput- Fig.31: Comparison between Manual and Computererized PDL for 112-63 Well.

ized PDL for 112-79 Well. 


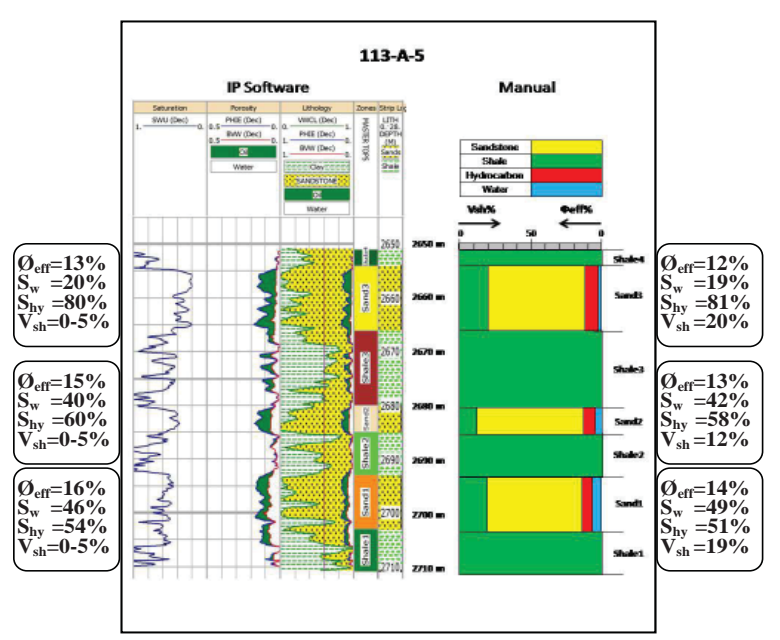

Fig.32: Comparison between Manual and Computerized PDL for 113-A-5 Well.

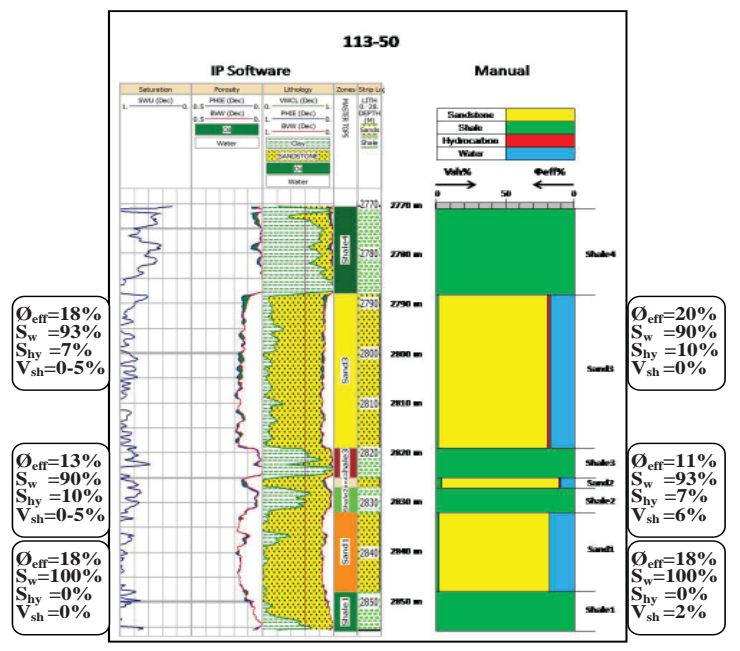

Fig.34: Comparison between Manual and Computerized PDL for 113-50 Well.

\section{SUMMARY AND CONCLUSIONS}

Belayim Land is a large oil field located in the central part of the Gulf of Suez, along the western coast of the Sinai Peninsula. The field was discovered in 1954 and put on production in 1955. Belayim Land is a multilayer field, with several separated sandstone reservoirs interbedded with shales and anhydrite intercalations. The hydrocarbon entrapment is formed by structural fault blocks.

This paper deals mainly with the quantitative interpretation of the available digital well-log data of nine wells scattered in the area of study, to delineate the hydrocarbon potentialities of Sidri Member. The well-log data are analyzed through a sequence of graphical relations to evaluate quantitatively the different petrophysical characteristics (manual interpretation) and

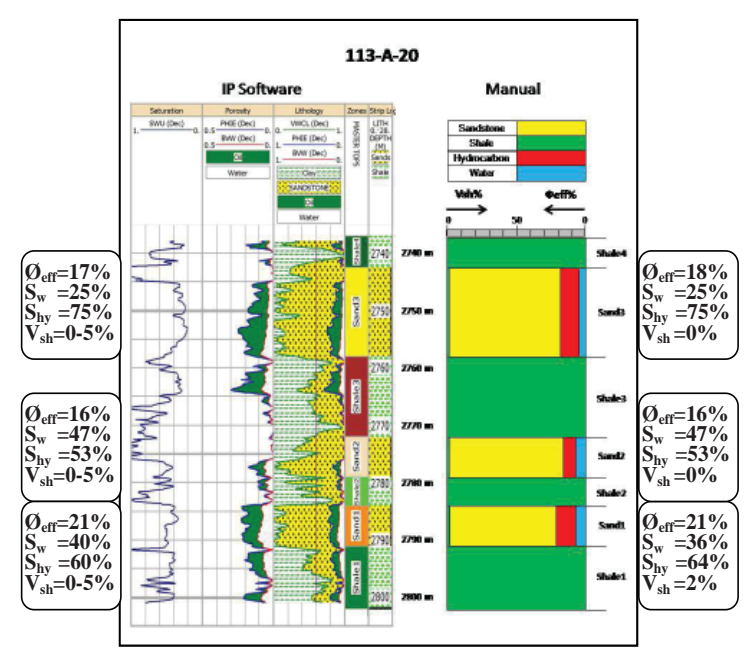

Fig.33: Comparison between Manual and Computerized PDL for 113-A-21 Well.

computerized by the available computer software. These petrophysical characteristics are the effective thickness $\left(\mathrm{H}_{\text {eff }}\right)$, shale content $\left(\mathrm{V}_{\mathrm{sh}}\right)$, effective porosity $\left(\varnothing_{\text {eff }}\right)$ and hydrocarbon saturation $\left(\mathrm{S}_{\mathrm{hr}}\right)$. The manual interpretation of the available well-logs was initiated by the conversion of the digital log data to hard copy, using the IP software. The studied member is subdivided into zones and the log readings for these zones were tabulated. These zones are correlated between wells, according to their remarkable changes in the log responses and their similarities.

Three sand layers and four shale layers are detected by using the Tri-porosity (M-N) crossplots for mineral identifications. Lithologic identification is achieved through the cross-plots between $\rho_{\mathrm{b}}, \varnothing_{\mathrm{n}}$ and $\Delta$ t, to detect the matrix density $\left(\rho_{\text {ma }}\right)$ and matrix interval transit time $\left(\Delta t_{\text {ma }}\right)$ for each layer. Mono-porosity cross-plots are built to detect the formation water resistivity $\left(\mathrm{R}_{\mathrm{w}}\right)$, Sonic, neutron and density derived porosities $\left(\varnothing_{\mathrm{s}}, \varnothing_{\mathrm{n}}\right.$ and $\left.\varnothing_{\mathrm{d}}\right)$, as well as the water and hydrocarbon saturations $\left(\mathrm{S}_{\mathrm{w}} \& \mathrm{~S}_{\mathrm{hr}}\right)$. Dia-porosity cross-plots, which are depending on a variety of combinations between the two porosity logreadings, were constructed to determine the shale volume $\left(\mathrm{V}_{\mathrm{sh}}\right)$ and effective porosity $\left(\varnothing_{\text {eff }}\right)$. Shale models also were constructed to determine the shale types within the area under investigation. The obtained petrophysical characteristics from the previous steps were plotted vertically in the form of petrophysical data logs (PDL). After the final evaluation, using computer softwere (IP), it was clear that, the litho-saturation cross-plots 
inferred from the computer processed interpretation (CPI) were matching very well with the manual ones. The lateral (horizontal) changes of the petrophysical characteristics for each sand level were displayed in the form of iso-parametric maps (effective thickness, shale content, effective porosity and hydrocarbon saturation).

The petrophysical characteristics of Sand 3 layer show that, the shale content increases relatively toward the southeastern part of the area under investigation and the maximum recorded value of shale content is $27 \%$ of $112-79$ well, which is decreasing gradually toward the northwest. The effective porosity increases toward the central part of the studied area around 11252 (BIS) and 112-63 wells. It has the maximum value of $24 \%$ toward $112-52$ (BIS) well and the minimum value is $12 \%$ recorded toward $112-\mathrm{A}$ 5 well at the southwestern part. The hydrocarbon saturation ranges from $75 \%$ to $92 \%$ and generally increases toward the southeastern part of the studied area. The hydrocarbon saturation has the maximum value at $112-63$ which is $92 \%$ and the minimum value recorded $75 \%$ at $113-\mathrm{A}-20$ well toward the western part.

The petrophysical characteristics of Sand 2 layer show that, the shale content increases relatively toward the northwestern and central parts around 112-56 and 112-52 (BIS) wells. The maximum recorded value of shale content is toward $112-56$ well which is $56 \%$, and the minimum value is toward the east, at 112-62 well. The effective porosity of Sand 2 layer decreases toward the central part of the studied area, around 112-52 (BIS) well. It has the maximum value $20 \%$ at $112-62$ well and the minimum value is about $3 \%$ recorded at $112-52$ (BIS) and $112-56$ wells. The hydrocarbon saturations range from $31 \%$ to $89 \%$ and generally increase toward the northeastern part of the studied area. It has the maximum value of $89 \%$ at $112-59$ well and the minimum value of $31 \%$ recorded at $112-52$ (BIS) well toward the southwestern part.

The petrophysical characteristics of Sand 1 layer show that, the shale content increases relatively toward the south of the area under investigation, around 113-A-5 well. The maximum recorded value of shale content $19 \%$ is at 113 A-5 well and the minimum values are toward the north in 112-62 and 112-63 wells. The effective porosity decreases toward the southwest of the studied area. It has the maximum value of $24 \%$ at 112-52 (BIS) and 112-79 wells and the minimum value of $14 \%$ recorded at $113-\mathrm{A}-5$ well. The hydrocarbon saturations range from $51 \%$ to $87 \%$ and generally increase to the northeastern part of the studied area. The hydrocarbon saturation has the maximum value of $87 \%$ at $112-59$ well and the minimum value of $51 \%$ recorded at 113-A-5 well toward the southwestern part.

From the previously mentioned conclusions, the petrophysical characteristics of Sidri Member (Sand 3, Sand 2 and Sand 1 layers) reflect the ability of these rock units to store and produce hydrocarbons. It is recommended to drill more development wells at the eastern part of the studied area to produce more hydrocarbons, especially from Sand 1 and Sand 3 layers, which still showing high hydrocarbon saturation with good porosities.

\section{REFERENCES}

Bosworth W., 1994, "Model for the Tree-Dimensional Evolution of Continental Rift Basins, North East Africa", H. Schandelmeier and R. J. Stern (eds), Geology of Northeast Africa (Part 2), pp. 671-688.

Burke J. A., Campbell R. L. and Schmidt A. W., 1969, "The Litho porosity Cross-plots", SPWLA, 10th Ann. Symp. Trans., pp. 1-29.

Darwin. V. Ells, 1987, "Well Logging for Earth Scientists", Elsevier Science Publishing Co., Inc. New York, pp. 401-447.

El-Kadi H. H., E. A. Abd EI-Gawad and A. M. Ghazaly, 2002, "Reservoir Characterization of the Upper Cretaceous Formations at Dabaa- Al Amein Area, North Western Desert, Egypt”, J. Appl. Geophs., Vol. 1, September 2002, pp. 33-52.

GEXCO and JEBCO, 1975, "Gulf of Suez Exploration Report”, JEBCO Exploration Co., Weybridge, Surrey, England.

McClay K. and Khalil S., 1998, "Extensional Tectonics and Sedimentation, Eastern Gulf of Suez, Egypt", B. H. Purser and D. W. J. Bosence (eds), Chapman and Hall, London, pp. 223-238.

Pirson, 1977, “Geologic Well Log Analysis", Gulf Publishing Company. Huston, London, Paris. pp. 165- 169.

Schlumberger, 1972, Log Interpretation Vol. I Principles. Schlumberger Limited, New York, U.S.A, p. 112.

Schlumberger, 1987, Log interpretation Principles /Application Schlumberger Educational Services, U.S.A, p. 168.

Schurmann H.M.E., 1971, "Tectonics of Africa: Gulf of Suez and the Northern Red Sea Area." UNESCO.

Youssef M. J., 1968, "Structural Pattern of Egypt and its Interpretation”, AAPG Bull., Vol. 52, n 4, pp. 601-614. 